\title{
Influence of Organic and Inorganic Sources of Nutrient on Nutrient Content and Uptake by Tikhur (Curcuma aungustifolia Roxb.) Grown in Inceptisol of Chhattisgarh Plateau
}

\author{
Karuna Kant Joshi* and Girijesh Kumar Sharma \\ Indira Gandhi Krishi Vishwavidyalaya, Shaheed Gundadhoor College of Agriculture and \\ Research Station, Jagdalpur-494005, (C.G.), India \\ *Corresponding author
}

\begin{tabular}{|c|c|}
\hline \multicolumn{2}{|r|}{ A B S T R A C T } \\
\hline & \multirow{6}{*}{ 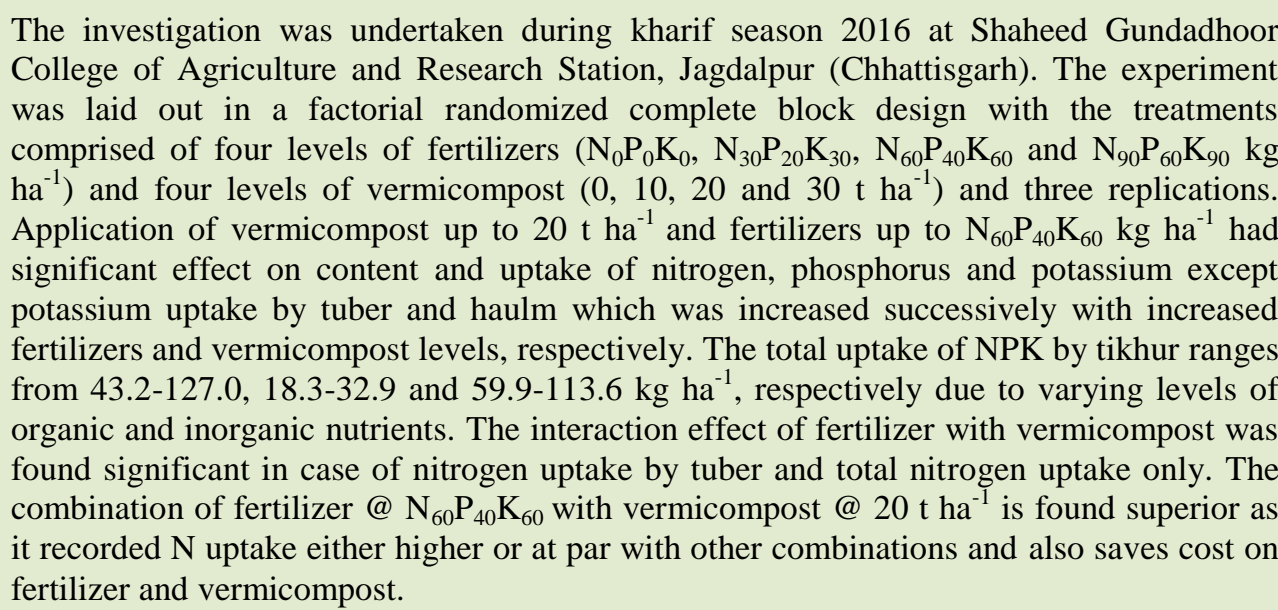 } \\
\hline & \\
\hline $\begin{array}{l}\text { Organic and inorganic } \\
\text { nutrients, NPK content } \\
\text { in Tikhur, NPK uptake } \\
\text { by Tikhur. }\end{array}$ & \\
\hline Article Info & \\
\hline $\begin{array}{l}\text { Accepted: } \\
\text { 10 September } 2017 \\
\text { Available Online: } \\
10 \text { November } 2017\end{array}$ & \\
\hline & \\
\hline
\end{tabular}

\section{Introduction}

Tikhur (Curcuma angustifolia; family Zingiberaceae) also known as white turmeric or East Indian arrowroot is a rhizomatous herb, which is considered as a minor tuber crop having medicinal value, grows well under shaded conditions, cultivated in many parts of the statesof Madhya Pradesh, Chhattisgarh and Jharkhand under moist deciduous mixed and sal forest. Its economic part is rhizome, which is used for the production of starch, valued as a food especially for infants, invalids and convalescents.
Additions of inorganic and organic nutrients are not only improves yield and quality of tuber and other crops but also exert significant influence on physical, chemical and biological properties of soil (Ramesan et al., 1996, Maheswarappa et al., 2000, Love, et al., 2005, Haase, et al., 2007 and Alam, 2007). The information on influence of organic and inorganic sources of nutrientson NPK content and uptake by Tikhur is meager. Hence a field investigation was initiated to evaluate the influence of organic and inorganic sources of nutrients on NPK content 
and uptake by Tikhur (Curcuma aungustifolia Roxb.) in Inceptisols of Chhattisgarh plateau.

\section{Materials and Methods}

The investigation was undertaken during the kharif season of 2016 at Indira Gandhi Krishi Vishwavidyalaya, Shaheed Gundadhoor College of Agriculture and Research Station, Jagdalpur, Bastar (Chhattisgarh). The experiment was laid out in a factorial randomized complete block design with the treatments comprised of four levels of fertilizers $\left(\mathrm{N}_{0} \mathrm{P}_{0} \mathrm{~K}_{0}, \mathrm{~N}_{30} \mathrm{P}_{20} \mathrm{~K}_{30}, \mathrm{~N}_{60} \mathrm{P}_{40} \mathrm{~K}_{60}\right.$ and $\left.\mathrm{N}_{90} \mathrm{P}_{60} \mathrm{~K}_{90} \mathrm{~kg} \mathrm{ha}{ }^{-1}\right)$ and four levels of vermicompost $\left(0,10,20\right.$ and $\left.30 \mathrm{t} \mathrm{ha}^{-1}\right)$ and three replications.

The experimental soil was loamy in texture, comes under Inceptisols order and had initial soil physicochemical properties like $46 \%$ sand, $30 \%$ silt, $24 \%$ clay, $5.5 \mathrm{pH}, 0.03 \mathrm{dSm}^{-1}$ electrical conductivity, $0.71 \%$ organic carbon, $1.43 \mathrm{~g} \mathrm{~cm}^{-3}$ bulk density, $14.5 \mathrm{C} \mathrm{mol}$ $(\mathrm{p}+) \mathrm{kg}^{-1}$ cation exchange capacity, $202.2 \mathrm{~kg}$ ha $^{-1}$ available $\mathrm{N}, 13.9 \mathrm{~kg} \mathrm{ha}^{-1}$ available P, 206 $\mathrm{kg} \mathrm{ha}^{-1}$ available $\mathrm{K}, 16.6 \mathrm{~kg} \mathrm{ha}^{-1}$ available $\mathrm{S}$, $2.51 \mathrm{meq} / 100 \mathrm{~g}$ available $\mathrm{Ca}, 1.82 \mathrm{meq} / 100 \mathrm{~g}$ soil available $\mathrm{Mg}$.

The nutritional composition of vermicompost used in the study was $1.4 \% \mathrm{~N}, 0.6 \% \mathrm{P}$ and $1.1 \% \mathrm{~K}$. The planting of Tikhur was done on May 17, 2016. Full dose of vermicompost, phosphorus and potassium and 1/3 dose of nitrogen, as per treatment, were applied in the form of diammonium phosphate, muriate of potash and urea, at the time of planting and the remaining dose of nitrogen was applied at 60 and 75 days after planting. The intercultural operation like, hand weeding done three times at 60,90 and 120 days after planting, earthing up done at 110 days after planting, spraying of macoban (carbendazim + mancozeb) fungicide for the control of blight disease at 100 days after sowing and crops are grown in rainfed field conditions. The crop was harvested at 30 December 2016 after complete maturity, as indicated by the leaf drying and falling down of plants.

For analysis of NPK content $0.5 \mathrm{~g}$ of dry well prepared plant samples are taken. The NPK uptake was calculated separately by multiplying their contents in tubers and haulm of tikhur with yield of tubers and haulm of tikhur. Total uptake of NPK was calculated separately by adding both components i.e uptake by tuber and uptake by haulm. The plant samples digested material was distilled by automatic KEL plus system and nitrogen content was determined using method as described by Chapman and Pratt (1961), phosphorus content was determined by vanadomolybdo-phosphoric acid yellow color complex method as described by Jackson (1973) and potassium content was determined by flame photometer as described by Chapman and Pratt (1961).

\section{Results and Discussion}

\section{Nitrogen content in tuber}

The data presented in table 1 revealed that the organic and inorganic nutrients individually had significant effect on nitrogen content in tuber, however, interaction of fertilizer with vermicompost was not found significant. Nitrogen content in the tuber ranges from 0.98 to $1.08 \%$ with the highest value due to application of fertilizer @ $\mathrm{N}_{90} \mathrm{P}_{60} \mathrm{~K}_{90} \mathrm{~kg} \mathrm{ha}^{-1}$ and vermicompost @ $30 \mathrm{t} \mathrm{ha}^{-1}$. The nitrogen content in tuber was significantly higher due to application of fertilizer @ $\mathrm{N}_{90} \mathrm{P}_{60} \mathrm{~K}_{90} \mathrm{~kg} \mathrm{ha}^{-1}$ as compared to $\mathrm{N}_{0} \mathrm{P}_{0} \mathrm{~K}_{0}$ and $\mathrm{N}_{30} \mathrm{P}_{20} \mathrm{~K}_{30} \mathrm{~kg} \mathrm{ha}^{-1}$ but at par with fertilizer @ $\mathrm{N}_{60} \mathrm{P}_{40} \mathrm{~K}_{60} \mathrm{~kg} \mathrm{ha}^{-1}$, similarly, application of vermicompost @ $30 \mathrm{t}$ ha ${ }^{-1}$ had recorded significantly higher nitrogen content in tuber than vermicompost @ 0 and $10 \mathrm{tha}^{-1}$ butit was at par with vermicompost @ $20 \mathrm{tha}^{-1}$. 


\section{Nitrogen content in haulm}

The data presented in table 1 revealed that the organic and inorganic nutrients individually had significant effect on nitrogen content in haulm of tikhur but their interaction was not found significant.

Nitrogen content in the haulm of tikhur ranges from 0.41 to $0.49 \%$ and 0.40 to $0.49 \%$ with the highest value due to application of fertilizer @ $\mathrm{N}_{90} \mathrm{P}_{60} \mathrm{~K}_{90} \mathrm{~kg} \mathrm{ha}^{-1}$ and vermicompost @ $30 \mathrm{tha}^{-1}$, respectively. The nitrogen content in haulm of tikhur was significantly higher due to application of fertilizer @ $\mathrm{N}_{90} \mathrm{P}_{60} \mathrm{~K}_{90} \mathrm{~kg} \mathrm{ha}^{-1}$ as compared to $\mathrm{N}_{0} \mathrm{P}_{0} \mathrm{~K}_{0}$ and $\mathrm{N}_{30} \mathrm{P}_{20} \mathrm{~K}_{30} \mathrm{~kg} \mathrm{ha}^{-1}$ but it was at par with fertilizer@ $\mathrm{N}_{60} \mathrm{P}_{40} \mathrm{~K}_{60} \mathrm{~kg} \mathrm{ha}^{-1}$, similarly, application of vermicompost @ $30 \mathrm{t} \mathrm{ha}^{-1} \mathrm{had}$ significantly higher nitrogen content in haulm of tikhur as compared to vermicompost @ 0 and $10 \mathrm{t} \mathrm{ha}^{-1}$ but it was at par with vermicompost@20 tha ${ }^{-1}$.

\section{Nitrogen uptake by tuber}

The data presented in table 1 and 4 revealed a significant individual and interaction effect of organic and inorganic nutrients on nitrogen uptake by tubers of tikhur. The nitrogen uptake by tubers of tikhur ranges from 61.3 to $113.5 \mathrm{~kg} \mathrm{ha}^{-1}$ and 75.3 to $105.6 \mathrm{~kg} \mathrm{ha}^{-1}$ with the highest value due to application of fertilizer @ $\mathrm{N}_{90} \mathrm{P}_{60} \mathrm{~K}_{90} \mathrm{~kg} \mathrm{ha}^{-1}$ and vermicompost @ $30 \mathrm{t}$ $\mathrm{ha}^{-1}$, respectively.

Significantly higher nitrogen uptake by tubers of tikhur was recorded due to application of fertilizer@ $\mathrm{N}_{90} \mathrm{P}_{60} \mathrm{~K}_{90} \mathrm{~kg} \mathrm{ha}^{-1}$ as compared to $\mathrm{N}_{0} \mathrm{P}_{0} \mathrm{~K}_{0}$ and $\mathrm{N}_{30} \mathrm{P}_{20} \mathrm{~K}_{30} \mathrm{~kg} \mathrm{ha}^{-1}$ but it was at par with $\mathrm{N}_{60} \mathrm{P}_{40} \mathrm{~K}_{60} \mathrm{~kg} \mathrm{ha}^{-1}$, similarly, the nitrogen uptake by tubers of tikhur was significantly higher due to application of vermicompost @ $30 \mathrm{t} \mathrm{ha}^{-1}$ as compared to vermicompost @ 0 and $10 \mathrm{t} \mathrm{ha}^{-1}$ but it was at par with vermicompost@20 tha ${ }^{-1}$.
In case of interaction effect, the nitrogen uptake by tubers of tikhur was increased under all the fertilizer levels as we increased vermicompost levels up to $20 \mathrm{t} \mathrm{ha}^{-1}$, increasing vermicompost levels, their after, did not increase nitrogen uptake by tuber, significantly. Similarly, the nitrogen uptake by tubers of tikhur was increased under all the vermicompost levels as we increased fertilizer levels up to $\mathrm{N}_{60} \mathrm{P}_{40} \mathrm{~K}_{60}$, increasing fertilizer level further did not statistically increase the nitrogen uptake by tubers. The higher nitrogen uptake by tuber $123.7 \mathrm{~kg} \mathrm{ha}^{-1}$ was achieved due to application of $30 \mathrm{t} \mathrm{ha}^{-1}$ vermicompost with fertilizer @ $\mathrm{N}_{90} \mathrm{P}_{60} \mathrm{~K}_{90} \mathrm{~kg}$ ha $^{-1}$ which was statistically at par with fertilizer@ $\mathrm{N}_{60} \mathrm{P}_{40} \mathrm{~K}_{60}$ with vermicompost @ 30 t ha ${ }^{-1}$, fertilizer @ $\mathrm{N}_{90} \mathrm{P}_{60} \mathrm{~K}_{90}$ with vermicompost@20 t ha ${ }^{-1}$ and fertilizer@ $\mathrm{N}_{60} \mathrm{P}_{40} \mathrm{~K}_{60}$ with vermicompost @ $20 \mathrm{t} \mathrm{ha}^{-1}$. It can be concluded that combination of fertilizer@ $\mathrm{N}_{60} \mathrm{P}_{40} \mathrm{~K}_{60}$ with vermicompost @ $20 \mathrm{t} \mathrm{ha}^{-1}$ is superior as it saves cost on fertilizer and vermicompost.

\section{Nitrogen uptake by haulm}

The data presented in table 1 revealed that the organic and inorganic nutrients individually had significant effect on nitrogen uptake by haulm of tikhur, however, their interaction was not found significant.

The nitrogen uptake by haulm ranges from 2.15 to $2.96 \mathrm{~kg} \mathrm{ha}^{-1}$ and 2.08 to $2.94 \mathrm{~kg} \mathrm{ha}^{-1}$ with the highest value due to application of fertilizer @ $\mathrm{N}_{90} \mathrm{P}_{60} \mathrm{~K}_{90} \mathrm{~kg} \mathrm{ha}^{-1}$ and vermicompost@30 tha ${ }^{-1}$, respectively. The nitrogen uptake by haulm was significantly higher due to application of fertilizer @ $\mathrm{N}_{90} \mathrm{P}_{60} \mathrm{~K}_{90} \mathrm{~kg} \mathrm{ha}^{-1}$ as compared to $\mathrm{N}_{0} \mathrm{P}_{0} \mathrm{~K}_{0}$ and $\mathrm{N}_{30} \mathrm{P}_{20} \mathrm{~K}_{30} \mathrm{~kg} \mathrm{ha}^{-1}$ but it was at par with $\mathrm{N}_{60} \mathrm{P}_{40} \mathrm{~K}_{60} \mathrm{~kg} \mathrm{ha}^{-1}$, similarly, application of vermicompost @ $30 \mathrm{t} \mathrm{ha}^{-1}$ had significantly higher nitrogen uptake by haulm than 0 and $10 \mathrm{tha}^{-1}$ but it was at par with $20 \mathrm{tha}^{-1}$. 


\section{Total nitrogen uptake}

The data presented in table 1 and 4 revealed that the organic and inorganic nutrients had significant individual and interaction effect on total nitrogen uptake by tikhur. The total nitrogen uptake ranges from 63.4 to $116.5 \mathrm{~kg}$ $\mathrm{ha}^{-1}$ and 77.4 to $108.5 \mathrm{~kg} \mathrm{ha}^{-1}$ with the highest value due to application of fertilizer @ $\mathrm{N}_{90} \mathrm{P}_{60} \mathrm{~K}_{90} \mathrm{~kg} \mathrm{ha}^{-1}$ and vermicompost @ $30 \mathrm{t}$ $\mathrm{ha}^{-1}$, respectively.

The total nitrogen uptake due to application of fertilizer @ $\mathrm{N}_{90} \mathrm{P}_{60} \mathrm{~K}_{90} \mathrm{~kg} \mathrm{ha}^{-1}$ was significantly higher than $\mathrm{N}_{0} \mathrm{P}_{0} \mathrm{~K}_{0}$ and $\mathrm{N}_{30} \mathrm{P}_{20} \mathrm{~K}_{30} \mathrm{~kg} \mathrm{ha}^{-1}$ but at par with $\mathrm{N}_{60} \mathrm{P}_{40} \mathrm{~K}_{60} \mathrm{~kg}$ $\mathrm{ha}^{-1}$, similarly, application of vermicompost @ $30 \mathrm{t} \mathrm{ha}^{-1}$ had significantly higher total nitrogen uptake as compared tovermicompost @ 0 and $10 \mathrm{t} \mathrm{ha}^{-1}$ but at par with vermicompost@20 tha ${ }^{-1}$.

In case of interaction effect, the total nitrogen uptake of tikhur was increased significantly under all the fertilizer levels, as we increased vermicompost levels up to $20 \mathrm{t} \mathrm{ha}^{-1}$, increasing vermicompost levels, their after, did not increase total nitrogen uptake significantly.

Similarly, the total nitrogen uptake of tikhur was increased significantly under all the vermicompost levels, as we increased fertilizer levels up to $\mathrm{N}_{60} \mathrm{P}_{40} \mathrm{~K}_{60}$, increasing fertilizer level further did not statistically increase the total nitrogen uptake.

The higher total nitrogen uptake $127 \mathrm{~kg} \mathrm{ha}^{-1}$ was achieved due to application of vermicompost@30t ha ${ }^{-1}$ with fertilizer@ $\mathrm{N}_{90} \mathrm{P}_{60} \mathrm{~K}_{90} \mathrm{~kg} \mathrm{ha}^{-1}$ which was statistically at par with fertilizer@ $\mathrm{N}_{60} \mathrm{P}_{40} \mathrm{~K}_{60}$ and vermicompost @ $30 \mathrm{t} \mathrm{ha}^{-1}$, fertilizer @ $\mathrm{N}_{90} \mathrm{P}_{60} \mathrm{~K}_{90}$ and vermicompost @20 t ha ${ }^{-1}$ and fertilizer@ $\mathrm{N}_{60} \mathrm{P}_{40} \mathrm{~K}_{60}$ with vermicompost @ $20 \mathrm{tha}{ }^{-1}$. It can be concluded that combination of fertilizer@ $\mathrm{N}_{60} \mathrm{P}_{40} \mathrm{~K}_{60}$ with vermicompost @
$20 \mathrm{t} \mathrm{ha}^{-1}$ is superior as it saves cost on fertilizer and vermicompost.

The similar findings were also recorded by several workers. Yourtchi et al., (2013) reported significantly higher nitrogen, potassium and phosphorous content of tuber due to application of $150 \mathrm{~kg} \mathrm{~N} \mathrm{ha}^{-1}$ and vermicompost@12t ha ${ }^{-1}$ in comparison to control.

Bashir and Qureshi (2014) reported that concentration of $\mathrm{N}, \mathrm{P}$ and $\mathrm{K}$ in tubers increased with increasing levels of $\mathrm{N}$ and FYM. Laxminarayana (2013) reported significantly higher total uptake of $\mathrm{N}(77.7 \mathrm{~kg}$ $\mathrm{ha}^{-1}$ ) due to integrated use of nutrients with an uptake response of $178 \%$ over control.

\section{Phosphorus content in tuber}

The data presented in table 2 revealed that the application of organic nutrients had significant effect on phosphorus content in tuber, however, application of inorganic nutrients and interaction of organic and inorganic nutrients was not found significant. The phosphorus content in tuber ranges from 0.27 to $0.32 \%$ with the highest value due to application of vermicompost @ 30t ha ${ }^{-1}$, which was significantly higher than 0 and $10 \mathrm{t}$ ha $a^{-1}$ but at par with $20 \mathrm{t} \mathrm{ha}^{-1}$.

\section{Phosphorus content in haulm}

The data presented in table 2 revealed that the organic nutrients had significant effect on phosphorus content in haulm, however, effect of inorganic nutrients and interaction of organic and inorganic nutrients were not found significant.

The phosphorus content in haulm ranges from 0.09 to $0.12 \%$ with the highest value due to application of vermicompost @ $30 \mathrm{t} \mathrm{ha}^{-1}$, which was significantly higher than 0 and $10 t$ $\mathrm{ha}^{-1}$ but at par with $20 \mathrm{t} \mathrm{ha}^{-1}$. 
Table.1 Effect of graded doses of inorganic and organic sources of nutrients on $\mathrm{N}$ content and uptake by Tikhur

\begin{tabular}{cccccc}
\hline Inorganic/ Organic dose & $\begin{array}{c}\mathrm{N} \text { content } \\
\text { in tuber } \\
(\%)\end{array}$ & $\begin{array}{c}\mathrm{N} \text { content } \\
\text { in haulm } \\
(\%)\end{array}$ & $\begin{array}{c}\text { Nuptake } \\
\text { by tuber } \\
\left(\mathrm{kg} \mathrm{ha}^{-1}\right)\end{array}$ & $\begin{array}{c}\mathrm{N} \text { uptake by } \\
\text { haulm } \\
\left(\mathrm{kg} \mathrm{ha}^{-1}\right)\end{array}$ & $\begin{array}{c}\text { Total N } \\
\text { uptake } \\
\left(\mathrm{kg} \mathrm{ha}^{-1}\right)\end{array}$ \\
\hline $\mathrm{N}_{0} \mathrm{P}_{0} \mathrm{~K}_{0}$ & $0.98^{\mathrm{a}}$ & $0.41^{\mathrm{a}}$ & $61.3^{\mathrm{a}}$ & $2.2^{\mathrm{a}}$ & $63.4^{\mathrm{a}}$ \\
$\mathrm{N}_{30} \mathrm{P}_{20} \mathrm{~K}_{30}$ & $1.00^{\mathrm{a}}$ & $0.43^{\mathrm{a}}$ & $86.7^{\mathrm{b}}$ & $2.3^{\mathrm{a}}$ & $89.0^{\mathrm{b}}$ \\
$\mathrm{N}_{60} \mathrm{P}_{40} \mathrm{~K}_{60}$ & $1.07^{\mathrm{b}}$ & $0.48^{\mathrm{ba}}$ & $111.6^{\mathrm{c}}$ & $2.7^{\mathrm{b}}$ & $114.3^{\mathrm{c}}$ \\
$\mathrm{N}_{90} \mathrm{P}_{60} \mathrm{~K}_{90}$ & $1.08^{\mathrm{b}}$ & $0.49^{\mathrm{b}}$ & $113.5^{\mathrm{c}}$ & $3.0^{\mathrm{b}}$ & $116.5^{\mathrm{c}}$ \\
\hline $\mathrm{CD}(\mathrm{P}=0.05)$ & 0.03 & 0.06 & 2.6 & 0.4 & 2.6 \\
\hline Vermicompost @ 0 $\mathrm{t} \mathrm{ha}^{-1}$ & $0.98^{\mathrm{a}}$ & $0.40^{\mathrm{a}}$ & $75.3^{\mathrm{a}}$ & $2.1^{\mathrm{a}}$ & $77.4^{\mathrm{a}}$ \\
Vermicompost @ $10 \mathrm{t} \mathrm{ha}^{-1}$ & $1.01^{\mathrm{a}}$ & $0.44^{\mathrm{a}}$ & $88.6^{\mathrm{b}}$ & $2.4^{\mathrm{a}}$ & $91.0^{\mathrm{b}}$ \\
Vermicompost @ 20 t ha ${ }^{-1}$ & $1.07^{\mathrm{b}}$ & $0.47^{\mathrm{ba}}$ & $103.6^{\mathrm{c}}$ & $2.7^{\mathrm{ba}}$ & $106.3^{\mathrm{c}}$ \\
Vermicompost @ 30 t ha ${ }^{-1}$ & $1.08^{\mathrm{b}}$ & $0.49^{\mathrm{b}}$ & $105.6^{\mathrm{c}}$ & $2.9^{\mathrm{b}}$ & $108.5^{\mathrm{c}}$ \\
\hline $\mathrm{CD}(\mathrm{P}=0.05)$ & 0.03 & 0.06 & 2.6 & 0.4 & 2.6 \\
\hline Interaction CD $\mathrm{P}=0.05)$ & $\mathrm{N} . \mathrm{S}$. & $\mathrm{N} . \mathrm{S}$. & 5.12 & $\mathrm{~N} . \mathrm{S}$. & 5.20 \\
\hline $\mathrm{CV}(\%)$ & 3.54 & 22.22 & 3.29 & 18.96 & 7.97 \\
\hline
\end{tabular}

Same small letter in a column have no significant difference as per Duncan's Multiple Range Test.

Table.2 Effect of graded doses of inorganic and organic sources of nutrients on Pcontent and uptake by Tikhur

\begin{tabular}{|c|c|c|c|c|c|}
\hline Inorganic/ Organic dose & $\begin{array}{l}\text { P content } \\
\text { in tuber } \\
(\%)\end{array}$ & $\begin{array}{c}\text { P content } \\
\text { in haulm } \\
(\%)\end{array}$ & $\begin{array}{c}\text { P uptake by } \\
\text { tuber } \\
\left(\mathrm{kg} \mathrm{ha}^{-1}\right)\end{array}$ & $\begin{array}{l}\text { P uptake by } \\
\text { haulm } \\
\left(\mathrm{kg} \mathrm{ha}^{-1}\right)\end{array}$ & $\begin{array}{c}\text { Total P } \\
\text { uptake } \\
\left(\mathrm{kg} \mathrm{ha}^{-1}\right) \\
\end{array}$ \\
\hline $\mathrm{N}_{0} \mathrm{P}_{0} \mathrm{~K}_{0}$ & 0.28 & 0.10 & $17.8^{\mathrm{a}}$ & $0.50^{\mathrm{a}}$ & $18.3^{\mathrm{a}}$ \\
\hline $\mathrm{N}_{30} \mathrm{P}_{20} \mathrm{~K}_{30}$ & 0.29 & 0.11 & $25.1^{\mathrm{b}}$ & $0.57^{\mathrm{a}}$ & $25.7^{\mathrm{b}}$ \\
\hline $\mathrm{N}_{60} \mathrm{P}_{40} \mathrm{~K}_{60}$ & 0.30 & 0.11 & $31.4^{\mathrm{c}}$ & $0.61^{\mathrm{ba}}$ & $32.0^{\mathrm{c}}$ \\
\hline $\mathrm{N}_{90} \mathrm{P}_{60} \mathrm{~K}_{90}$ & 0.31 & 0.11 & $32.2^{\mathrm{c}}$ & $0.68^{\mathrm{b}}$ & $32.9^{\mathrm{c}}$ \\
\hline $\mathrm{CD}(\mathrm{P}=0.05)$ & N.S. & N.S. & 1.8 & 0.11 & 1.9 \\
\hline Vermicompost @ 0 tha $^{-1}$ & $0.27^{\mathrm{a}}$ & $0.09^{\mathrm{a}}$ & $20.9^{\mathrm{a}}$ & $0.49^{\mathrm{a}}$ & $21.4^{\mathrm{a}}$ \\
\hline Vermicompost @ $10 \mathrm{tha}^{-1}$ & $0.29^{\mathrm{a}}$ & $0.10^{\mathrm{a}}$ & $25.3^{\mathrm{b}}$ & $0.53^{\mathrm{a}}$ & $25.8^{\mathrm{b}}$ \\
\hline Vermicompost @20t ha ${ }^{-1}$ & $0.30^{\mathrm{ba}}$ & $0.11^{\text {ba }}$ & $29.4^{\mathrm{c}}$ & $0.63^{\text {ba }}$ & $30.1^{\mathrm{c}}$ \\
\hline Vermicompost @ $30 \mathrm{tha}^{-1}$ & $0.32^{\mathrm{b}}$ & $0.12^{\mathrm{b}}$ & $30.9^{c}$ & $0.72^{\mathrm{b}}$ & $31.6^{\mathrm{c}}$ \\
\hline $\mathrm{CD}(\mathrm{P}=0.05)$ & 0.02 & 0.01 & 1.8 & 0.11 & 1.9 \\
\hline Interaction $\mathrm{CD}(\mathrm{P}=0.05)$ & N.S. & N.S. & N.S. & N.S. & N.S. \\
\hline $\mathrm{CV}(\%)$ & 8.75 & 17.39 & 8.26 & 23.97 & 8.26 \\
\hline
\end{tabular}

Same small letter in a column have no significant difference as per Duncan's Multiple Range Test. 
Table.3 Effect of graded doses of inorganic and organic sources of nutrients on K content and uptake by Tikhur

\begin{tabular}{cccccc}
\hline Inorganic/ Organic dose & $\begin{array}{c}\text { K content } \\
\text { in tuber } \\
(\%)\end{array}$ & $\begin{array}{c}\text { K content } \\
\text { in haulm } \\
(\%)\end{array}$ & $\begin{array}{c}\text { K uptake } \\
\text { by tuber } \\
\left(\mathrm{kg} \mathrm{ha}^{-1}\right)\end{array}$ & $\begin{array}{c}\text { K uptake by } \\
\text { haulm } \\
\left(\mathrm{kg} \mathrm{ha}^{-1}\right)\end{array}$ & $\begin{array}{c}\text { Total K } \\
\text { uptake } \\
\left(\mathrm{kg} \mathrm{ha}^{-1}\right)\end{array}$ \\
\hline $\mathrm{N}_{0} \mathrm{P}_{0} \mathrm{~K}_{0}$ & $0.94^{\mathrm{a}}$ & $0.10^{\mathrm{a}}$ & $59.4^{\mathrm{a}}$ & $0.50^{\mathrm{a}}$ & $59.9^{\mathrm{a}}$ \\
$\mathrm{N}_{30} \mathrm{P}_{20} \mathrm{~K}_{30}$ & $0.99^{\mathrm{a}}$ & $0.11^{\mathrm{b}}$ & $85.3^{\mathrm{b}}$ & $0.60^{\mathrm{b}}$ & $85.8^{\mathrm{b}}$ \\
$\mathrm{N}_{60} \mathrm{P}_{40} \mathrm{~K}_{60}$ & $1.02^{\mathrm{ba}}$ & $0.13^{\mathrm{c}}$ & $106.4^{\mathrm{c}}$ & $0.74^{\mathrm{c}}$ & $107.2^{\mathrm{c}}$ \\
$\mathrm{N}_{90} \mathrm{P}_{60} \mathrm{~K}_{90}$ & $1.07^{\mathrm{b}}$ & $0.14^{\mathrm{c}}$ & $112.9^{\mathrm{d}}$ & $0.83^{\mathrm{c}}$ & $113.6^{\mathrm{c}}$ \\
\hline $\mathrm{CD}(\mathrm{P}=0.05)$ & 0.06 & 0.01 & 6.3 & 0.09 & 6.4 \\
\hline Vermicompost @ 0 t ha ${ }^{-1}$ & $0.92^{\mathrm{a}}$ & $0.10^{\mathrm{a}}$ & $70.9^{\mathrm{a}}$ & $0.51^{\mathrm{a}}$ & $71.4^{\mathrm{a}}$ \\
Vermicompost @ 10 t ha ${ }^{-1}$ & $0.98^{\mathrm{a}}$ & $0.11^{\mathrm{b}}$ & $86.0^{\mathrm{b}}$ & $0.62^{\mathrm{b}}$ & $86.6^{\mathrm{b}}$ \\
Vermicompost @ 20 t ha ${ }^{-1}$ & $1.03^{\mathrm{ba}}$ & $0.13^{\mathrm{c}}$ & $100.4^{\mathrm{c}}$ & $0.72^{\mathrm{c}}$ & $101.1^{\mathrm{c}}$ \\
Vermicompost @ 30 t ha ${ }^{-1}$ & $1.08^{\mathrm{b}}$ & $0.14^{\mathrm{c}}$ & $106.5^{\mathrm{c}}$ & $0.82^{\mathrm{d}}$ & $107.4^{\mathrm{c}}$ \\
\hline $\mathrm{CD}(\mathrm{P}=0.05)$ & 0.06 & 0.01 & 6.3 & 0.09 & 6.4 \\
\hline Interaction CD $(\mathrm{P}=0.05)$ & $\mathrm{N} . \mathrm{S}$. & $\mathrm{N} . \mathrm{S}$. & $\mathrm{N} . \mathrm{S}$. & $\mathrm{N} . \mathrm{S}$. & $\mathrm{N} . \mathrm{S}$. \\
\hline $\mathrm{CV}(\%)$ & 10.0 & 15.14 & 6.02 & 14.93 & 8.33 \\
\hline Sam $)$ &
\end{tabular}

Same small letter in a column have no significant difference as per Duncan's Multiple Range Test.

Table.4 Interaction effect of graded doses of inorganic and organic sources of nutrients on $\mathrm{N}$ uptake by Tikhur

\begin{tabular}{|c|c|c|c|c|c|}
\hline \multirow{2}{*}{$\begin{array}{l}\text { Fertilizer levels } \\
\left(\mathrm{kg} \mathrm{ha}^{-1}\right)\end{array}$} & \multicolumn{4}{|c|}{ Vermicompost levels $\left(\mathrm{t} \mathrm{ha}^{-1}\right)$} & \multirow{2}{*}{$\begin{array}{c}\text { Interaction } \\
\mathrm{CD}(P=0.05)\end{array}$} \\
\hline & 0 & 10 & 20 & 30 & \\
\hline \multicolumn{6}{|c|}{ N uptake by tuber $\left(\mathrm{kg} \mathrm{ha}^{-1}\right)$} \\
\hline $\mathrm{N}_{0} \mathrm{P}_{0} \mathrm{~K}_{0}$ & $41.5^{\mathrm{aA}}$ & $54.6^{\mathrm{aB}}$ & $73.6^{\mathrm{aC}}$ & $75.4^{\mathrm{aC}}$ & \multirow{4}{*}{5.1} \\
\hline $\mathrm{N}_{30} \mathrm{P}_{20} \mathrm{~K}_{30}$ & $63.6^{\mathrm{bA}}$ & $82.1^{\mathrm{bB}}$ & $99.3^{\mathrm{bC}}$ & $101.7^{\mathrm{bC}}$ & \\
\hline $\mathrm{N}_{60} \mathrm{P}_{40} \mathrm{~K}_{60}$ & $96.8^{\mathrm{cA}}$ & $107.6^{\mathrm{cB}}$ & $120.2^{\mathrm{cC}}$ & $121.6^{\mathrm{cC}}$ & \\
\hline $\mathrm{N}_{90} \mathrm{P}_{60} \mathrm{~K}_{90}$ & $99.3^{\mathrm{cA}}$ & $109.9^{\mathrm{cB}}$ & $121.2^{\mathrm{cC}}$ & $123.7^{\mathrm{cC}}$ & \\
\hline \multicolumn{6}{|c|}{ Total N uptake (kg ha $\left.{ }^{-1}\right)$} \\
\hline $\mathrm{N}_{0} \mathrm{P}_{0} \mathrm{~K}_{0}$ & $43.2^{\mathrm{aA}}$ & $56.6^{\mathrm{aB}}$ & $75.9^{\mathrm{aC}}$ & $78.0^{\mathrm{aC}}$ & \multirow{4}{*}{5.2} \\
\hline $\mathrm{N}_{30} \mathrm{P}_{20} \mathrm{~K}_{30}$ & $65.5^{\mathrm{bA}}$ & $84.3^{\mathrm{bB}}$ & $101.7^{\mathrm{bC}}$ & $104.4^{\mathrm{bC}}$ & \\
\hline $\mathrm{N}_{60} \mathrm{P}_{40} \mathrm{~K}_{60}$ & $99.0^{\mathrm{cA}}$ & $110.2^{\mathrm{cB}}$ & $123.2^{\mathrm{cC}}$ & $124.7^{\mathrm{cC}}$ & \\
\hline $\mathrm{N}_{90} \mathrm{P}_{60} \mathrm{~K}_{90}$ & $101.8^{\mathrm{cA}}$ & $112.7^{\mathrm{cB}}$ & $124.4^{\mathrm{cC}}$ & $127.0^{\mathrm{cC}}$ & \\
\hline
\end{tabular}

Same capital letter in a row and small letter in a column have no significant difference as per Duncan's Multiple Range Test.

\section{Phosphorus uptake by tuber}

The data presented in table 2 revealed that the organic and inorganic nutrients individually had significant effect on phosphorus uptake by tuber but their interaction was not found significant. The phosphorus uptake by tuber ranges from 17.8 to $32.2 \mathrm{~kg} \mathrm{ha}^{-1}$ and 20.9 to
$30.9 \mathrm{~kg} \mathrm{ha}^{-1}$, with the highest value due to application of fertilizer @ $\mathrm{N}_{90} \mathrm{P}_{60} \mathrm{~K}_{90} \mathrm{~kg} \mathrm{ha}^{-1}$ and vermicompost @30 tha ${ }^{-1}$, respectively. The phosphorus uptake by tuber was significantly higher due to application of fertilizer@ $\mathrm{N}_{90} \mathrm{P}_{60} \mathrm{~K}_{90} \mathrm{~kg} \mathrm{ha}^{-1}$ as compared to $\mathrm{N}_{0} \mathrm{P}_{0} \mathrm{~K}_{0}$ and $\mathrm{N}_{30} \mathrm{P}_{20} \mathrm{~K}_{30} \mathrm{~kg}^{-1}$ hat at par with $\mathrm{N}_{60} \mathrm{P}_{40} \mathrm{~K}_{60} \mathrm{~kg} \mathrm{ha}^{-1}$, similarly, phosphorus 
uptake by tuber was significantly higher due to application of vermicompost @ $30 \mathrm{t} \mathrm{ha}^{-1}$ as compared to 0 and $10 \mathrm{t} \mathrm{ha}^{-1}$ but at par with $20 \mathrm{t}$ $\mathrm{ha}^{-1}$.

\section{Phosphorus uptake by haulm}

The data presented in table 2 revealed that the organic and inorganic nutrients individually had significant effect on phosphorus uptake by haulm, however, their interaction was not found significant. The phosphorus uptake by haulm ranges from 0.50 to $0.68 \mathrm{~kg} \mathrm{ha}^{-1}$ and 0.49 to $0.72 \mathrm{~kg} \mathrm{ha}^{-1}$ with the highest value due to application of fertilizer @ $\mathrm{N}_{90} \mathrm{P}_{60} \mathrm{~K}_{90} \mathrm{~kg} \mathrm{ha}^{-1}$ and vermicompost@30 t ha ${ }^{-1}$, respectively. The phosphorus uptake by haulm was significantly higher due to application of fertilizer@ $\mathrm{N}_{90} \mathrm{P}_{60} \mathrm{~K}_{90} \mathrm{~kg} \mathrm{ha}^{-1}$ as compared to $\mathrm{N}_{0} \mathrm{P}_{0} \mathrm{~K}_{0}$ and $\mathrm{N}_{30} \mathrm{P}_{20} \mathrm{~K}_{30} \mathrm{~kg} \mathrm{ha}^{-1}$ but at par with $\mathrm{N}_{60} \mathrm{P}_{40} \mathrm{~K}_{60} \mathrm{~kg} \mathrm{ha}^{-1}$, similarly, phosphorus uptake by haulm was significantly higher due to application of vermicompost @ $30 \mathrm{t} \mathrm{ha}^{-1}$ as compared to 0 and $10 \mathrm{t} \mathrm{ha}^{-1}$ but at par with 20 $\mathrm{t} \mathrm{ha}^{-1}$.

\section{Total phosphorus uptake}

The data presented in table 2 revealed that the organic and inorganic nutrients individually had significant effect on total phosphorus uptake, however, their interaction was not found significant. The total phosphorus uptake ranges from 18.3 to $32.9 \mathrm{~kg} \mathrm{ha}^{-1}$ and 21.4 to $31.6 \mathrm{~kg} \mathrm{ha}^{-1}$ with the highest value due to application of fertilizer @ $\mathrm{N}_{90} \mathrm{P}_{60} \mathrm{~K}_{90} \mathrm{~kg} \mathrm{ha}^{-1}$ and vermicompost @ $30 \mathrm{t} \mathrm{ha}^{-1}$. The total phosphorus uptake was significantly higher due to application of fertilizer @ $\mathrm{N}_{90} \mathrm{P}_{60} \mathrm{~K}_{90} \mathrm{~kg}$ $\mathrm{ha}^{-1}$ as compared to $\mathrm{N}_{0} \mathrm{P}_{0} \mathrm{~K}_{0}$ and $\mathrm{N}_{30} \mathrm{P}_{20} \mathrm{~K}_{30} \mathrm{~kg}$ ha ${ }^{-1}$ but at par with $\mathrm{N}_{60} \mathrm{P}_{40} \mathrm{~K}_{60} \mathrm{~kg} \mathrm{ha}^{-1}$, similarly, application of vermicompost @ $30 \mathrm{t}$ $\mathrm{ha}^{-1}$ was significantly higher than 0 and $10 \mathrm{t}$ $\mathrm{ha}^{-1}$ and at par with $20 \mathrm{t} \mathrm{ha}^{-1}$. The similar findings were also reported by several workers. The concentration of $\mathrm{N}, \mathrm{P}$ and $\mathrm{K}$ in tubers increased with increasing levels of $\mathrm{N}$ and FYM (Bashir and Qureshi, 2014). Yourtchi et al., (2013) reported that effects of different nitrogen rates and vermicompost application significantly improved NPK content of tuber compared with nitrogen or vermicompost alone treatments. Laxminarayana (2013) reported that total uptake of $\mathrm{P}$ was the highest due to integrated use of nutrients.

\section{Potassium content in tuber}

The data presented in table 3 revealed that the organic and inorganic nutrients individually had significant effect on potassium content in tuber but their interaction was not found significant. The potassium content in tuber ranges from 0.94 to $1.07 \%$ and 0.92 to1.08\%with the highest value due to application of fertilizer @ $\mathrm{N}_{90} \mathrm{P}_{60} \mathrm{~K}_{90} \mathrm{~kg} \mathrm{ha}^{-1}$ and vermicompost @30t ha ${ }^{-1}$, respectively. The potassium content in tuber was significantly higher due to application of fertilizer@ $\mathrm{N}_{90} \mathrm{P}_{60} \mathrm{~K}_{90} \mathrm{~kg} \mathrm{ha}^{-1}$ as compared to $\mathrm{N}_{0} \mathrm{P}_{0} \mathrm{~K}_{0}$ and $\mathrm{N}_{30} \mathrm{P}_{20} \mathrm{~K}_{30} \mathrm{~kg} \mathrm{ha}^{-1}$ but at par with $\mathrm{N}_{60} \mathrm{P}_{40} \mathrm{~K}_{60} \mathrm{~kg} \mathrm{ha}^{-1}$, similarly, potassium content in tuber was found significantly higher due to application of vermicompost @ 30t ha ${ }^{-1}$ as compared to 0 and $10 \mathrm{t} \mathrm{ha}^{-1}$ but at par with 20 $\mathrm{tha}^{-1}$.

\section{Potassium content in haulm}

The data presented in table 3 revealed that the organic and inorganic nutrients individually had significant effect on potassium content in haulm but their interaction was not found significant. Potassium content in haulm ranges from 0.10 to $0.14 \%$ with the highest value due to application of fertilizer@ $\mathrm{N}_{90} \mathrm{P}_{60} \mathrm{~K}_{90} \mathrm{~kg} \mathrm{ha}^{-1}$ and vermicompost @ 30t $\mathrm{ha}^{-1}$. The potassium content in haulm was significantly higher due to application of fertilizer @ $\mathrm{N}_{90} \mathrm{P}_{60} \mathrm{~K}_{90} \mathrm{~kg} \mathrm{ha}^{-1}$ as compared to $\mathrm{N}_{0} \mathrm{P}_{0} \mathrm{~K}_{0}$ and $\mathrm{N}_{30} \mathrm{P}_{20} \mathrm{~K}_{30} \mathrm{~kg} \mathrm{ha}^{-1}$ but at par with 
$\mathrm{N}_{60} \mathrm{P}_{40} \mathrm{~K}_{60} \mathrm{~kg}$ ha $^{-1}$, similarly, potassium content in haulm was found significantly higher due to application of vermicompost @ $30 \mathrm{t} \mathrm{ha}^{-1}$ as compared to 0 and $10 \mathrm{t} \mathrm{ha}^{-1}$ but at par with 20 $\mathrm{t} \mathrm{ha}^{-1}$.

\section{Potassium uptake by tuber}

The data presented in table 3 revealed that the organic and inorganic nutrients individually had significant effect on potassium uptake by tuber, however, their interaction was not found significant.

The potassium uptake by tuber ranges from 59.4 to $112.9 \mathrm{~kg} \mathrm{ha}^{-1}$ and 70.9 to $106.5 \mathrm{~kg} \mathrm{ha}^{-1}$ with the highest value due to application of fertilizer @ $\mathrm{N}_{90} \mathrm{P}_{60} \mathrm{~K}_{90} \mathrm{~kg} \mathrm{ha}^{-1}$ and vermicompost @ $30 \mathrm{t} \mathrm{ha}^{-1}$, respectively. Potassium uptake by tuber increased significantly at all successive fertilizer levels from $\mathrm{N}_{0} \mathrm{P}_{0} \mathrm{~K}_{0}$ to $\mathrm{N}_{30} \mathrm{P}_{20} \mathrm{~K}_{30} \mathrm{~kg} \mathrm{ha}^{-1}, \mathrm{~N}_{30} \mathrm{P}_{20} \mathrm{~K}_{30}$ to $\mathrm{N}_{60} \mathrm{P}_{40} \mathrm{~K}_{60}$ and $\mathrm{N}_{60} \mathrm{P}_{40} \mathrm{~K}_{60}$ to $\mathrm{N}_{90} \mathrm{P}_{60} \mathrm{~K}_{90} \mathrm{~kg} \mathrm{ha}^{-1}$. Whereas, potassium uptake by tuber was significantly higher due to application of vermicompost@30t ha ${ }^{-1}$ as compared to 0 and $10 \mathrm{t} \mathrm{ha}^{-1}$ but at par with $20 \mathrm{t} \mathrm{ha}^{-1}$.

\section{Potassium uptake by haulm}

The data presented in table 3 revealed that the organic and inorganic nutrients individually had significant effect on uptake by haulm but their interaction was not found significant. The potassium uptake by haulm ranges from 0.50 to $0.83 \mathrm{~kg} \mathrm{ha}^{-1}$ and 0.51 to $0.82 \mathrm{~kg} \mathrm{ha}^{-1}$ with the highest value due to application of fertilizer @ $\mathrm{N}_{90} \mathrm{P}_{60} \mathrm{~K}_{90} \mathrm{~kg} \quad \mathrm{ha}^{-1}$ and vermicompost@30 t ha ${ }^{-1}$, respectively. The potassium uptake by haulm was significantly higher due to application of fertilizer @ $\mathrm{N}_{90} \mathrm{P}_{60} \mathrm{~K}_{90} \mathrm{~kg}^{-1}$ as compared to $\mathrm{N}_{0} \mathrm{P}_{0} \mathrm{~K}_{0}$ and $\mathrm{N}_{30} \mathrm{P}_{20} \mathrm{~K}_{30} \mathrm{~kg} \mathrm{ha}^{-1}$ but at par with $\mathrm{N}_{60} \mathrm{P}_{40} \mathrm{~K}_{60} \mathrm{~kg}$ $\mathrm{ha}^{-1}$. Whereas, Potassium uptake by haulm increased significantly at all successive vermicompost levels from 0 to 10,10 to 20 and 20to $30 \mathrm{tha}^{-1}$.

\section{Total potassium uptake}

The data presented in table 3 revealed that the organic and inorganic nutrients individually had significant effect on total potassium uptake, however, their interaction was not found significant. The total potassium uptake ranges from 59.9 to $113.6 \mathrm{~kg} \mathrm{ha}^{-1}$ and 71.4 to $107.4 \mathrm{~kg} \mathrm{ha}^{-1}$ with the highest value due to application of fertilizer @ $\mathrm{N}_{90} \mathrm{P}_{60} \mathrm{~K}_{90} \mathrm{~kg} \mathrm{ha}^{-1}$ and vermicompost @ $30 \mathrm{t} \mathrm{ha}^{-1}$ respectively. The total potassium uptake was significantly higher due to application of fertilizer @ $\mathrm{N}_{90} \mathrm{P}_{60} \mathrm{~K}_{90} \mathrm{~kg} \mathrm{ha}^{-1}$ as compared to $\mathrm{N}_{0} \mathrm{P}_{0} \mathrm{~K}_{0}$ and $\mathrm{N}_{30} \mathrm{P}_{20} \mathrm{~K}_{30} \mathrm{~kg} \mathrm{ha}^{-1}$ but at par with $\mathrm{N}_{60} \mathrm{P}_{40} \mathrm{~K}_{60} \mathrm{~kg}$ $\mathrm{ha}^{-1}$, similarly, total potassium uptake was found significantly higher due to application of vermicompost @ $30 \mathrm{t} \mathrm{ha}^{-1}$ as compared to 0 and $10 \mathrm{t} \mathrm{ha}^{-1}$ but at par with $20 \mathrm{t} \mathrm{ha}^{-1}$.

The similar findings were also recorded by Yourtchi et al., (2013), Bashir and Qureshi (2014) and Laxminarayana (2013).

\section{References}

Alam, M. N., Jahan, M. S., Ali, M. K., Ashraf, M. A. and Islam, M. K. 2007.Effect of vermicompost and chemical fertilizers on growth, yield and yield components of potato in barind soils of Bangladesh. J. Appl. Sci. Res., 3(12): 1879-1888.

Bashir, U. and Qureshi, F. 2014. Effect of nitrogen and farmyard manure on yield, nutrient content and quality of potato (Solanum tuberosum L.).An international quarterly journal of biology \& life sciences, 2(3):786-791.

Chapman, H. D. and Pratt, P. F.1961.Methods of analysis for soils, plants, and waters. Univ. Calif., Div. Agr. Sci., Berkeley, Calif. 309 p.

Haase, T., Schuler, C. and Heb, J. 2007.The effect of different $\mathrm{N}$ and $\mathrm{K}$ sources on tuber nutrient uptake, total and graded 
yield of potatoes (Solanum tuberosum L.) for processing. Euro. J. Agron, 26: 187-197.

Jackson, M. L. 1973. Soil chemical Analysis, Prentice Hall of India Private Limited, New Delhi.

Laxminarayana, K. 2013. Impact of INM on Soil Quality, Yield, Proximate Composition and Nutrient Uptake of Sweet Potato in Alfisols. Journal of Root Crops, 39(1):48-55.

Love, S. L., Stark, J. C. and Salaiz, T. 2005.Response of four potato cultivars to rate and timing of nitrogen fertilizer. Am. J. Pot. Res., 82: 21-31.

Maheswarappa, H.P., Nanjappa, H.V., Hegde, M.R. and Biddappa, C.C. 2000.Nutrient content and uptake of arrowroot (Maranta arundinacea) as influenced by agronomic practices when grown as an intercrop in coconut (Cocos nucifera) garden. Indian J. Agron., 45:86-91.

Ramesan, K. K., Ahmed, P. and Oommen, M. 1996. Management of major plant nutrients for producing quality rhizomes in arrowroot. In: Proceedings of the 8th Kerala Science Congress Kerala State Council for Science, Technology and Environment, Government of Kerala, Kochi, pp.133-134.

Yourtchi, M. S., Hadi, M. H. S. and Darzi, M. T. 2013. Effect of nitrogen fertilizer and vermicompost on vegetative growth, yield and NPK uptake by tuber of potato (Agria CV.). Intl J Agri Crop Sci., 5(18): 2033-2040.

\section{How to cite this article:}

Karuna Kant Joshi and Girijesh Kumar Sharma. 2017. Influence of Organic and Inorganic Sources of Nutrient on Nutrient Content and Uptake by Tikhur (Curcuma aungustifolia Roxb.) Grown in Inceptisol of Chhattisgarh Plateau. Int.J.Curr.Microbiol.App.Sci. 6(11): 1021-1029. doi: https://doi.org/10.20546/ijcmas.2017.611.119 